УДК 811.111 '373.43

DOI https://doi.org/10.26661/2414-1135-2021-84-37

\title{
НЕОЛОГІЗМИ В АНГЛОМОВНИХ РЕКЛАМНИХ ТЕКСТАХ Б’ЮТІ-ІНДУСТРІЇ
}

\author{
Хавкіна О. М. \\ кандидат філологічних наук, доцент, \\ дочент кафедри теорії та практики перекладу \\ Національний університет «Запорізька політехніка» \\ вул. Жуковського, 64, Запоріжжя, Украӥна \\ orcid.org/0000-0001-6673-5382 \\ yelnik@ukr.net \\ Чуприна К. О. \\ студентка кафедри теорії та практики перекладу \\ Національний університет «Запорізька політехніка» \\ вул. Жуковського, 64, Запоріжжя, Украӥна \\ orcid.org/0000-0002-2002-6529 \\ ivanenkova.kristina1069@gmail.com
}

Ключові слова: інновація, запозичення, лексичні неологізми, семантичні неологізми, авторські неологізми, абревіатури, словоскладання, афіксація, телескопія.
У статті висвітлюються основні закономірності утворення та функціонування неологізмів у сучасних англомовних текстах б'ютііндустрії. Авторами порушується питання розмежування понять «неологізм» та «інновація» 3 огляду на різні погляди вітчизняних та закордонних лінгвістів на сучасному етапі розвитку мовознавчої науки. Також було розглянуто важливість уживання неологічної лексики в рекламних текстах як одного з потужних інструментів розкрутки та просунення товарів та послуг на ринку сфери краси.

Серед проаналізованих інновацій найчисленнішими $\epsilon$ іменники, рідшими є прикметники, ще рідшими - дієслова. Така непропорційність частиномовної приналежності досліджених лексем може бути пов'язана 3 необхідністю називати нові процедури і продукти, що активно з'являються в б'юті-сфері. У статті розглядаються основні структурно-граматичні та лексико-семантичні особливості неологізмів, використовуваних рекламодавцями для ефективного привернення уваги потенційних покупців до відповідного продукту, засобу чи процедури. За способом утворення всі проаналізовані інновації можуть бути розподілені на лексичні, семантичні, авторські (індивідуально-стилістичні) і абревіатури. Також у статті аналізуються основні морфологічні способи словотворення неологізмів, що функціонують у текстах б'юті-індустрії: словоскладання, афіксація і телескопія. Корпус дослідження головним чином репрезентований прикметниково-іменними сполуками, що розподіляються на декілька підтипів. Іменні сполуки утворюються за словотворчими моделями $\mathrm{N}+\mathrm{N}, \mathrm{V}+\mathrm{N}, \mathrm{Adj}+\mathrm{N}$. Прикметникові сполуки будуються за моделями V + Adj, Adj + Adj.

Щодо семантики проаналізованих інновацій, то їх було розподілено між чотирма семантичними групами: косметичні засоби, напрями естетичної медицини і косметології, косметичні й оздоровчі методики і процедури, лексеми для опису декоративної косметики та косметичних засобів.

Велику увагу приділено питанню розширення лексичного складу б'ютііндустрії завдяки процесам запозичення іншомовних словесних знаків і використання актуальних словотворчих можливостей. 


\title{
NEOLOGISMS IN ENGLISH ADVERTISING TEXTS OF THE BEAUTY INDUSTRY
}

\author{
Khavkina O. M. \\ Candidate of Philological Sciences, Associate Professor, \\ Associate Professor at the Department of Translation Theory and Practice \\ Zaporizhzhia Polytechnic National University \\ Zhukovskoho str., 64, Zaporizhzhia, Ukraine \\ orcid.org/0000-0001-6673-5382 \\ yelnik@ukr.net \\ Chuprina K. O. \\ Master Student at the Department of Translation Theory and Practice \\ Zaporizhzhya Polytechnic National University \\ Zhukovskoho str., 64, Zaporizhzhia, Ukraine \\ orcid.org/0000-0002-2002-6529 \\ ivanenkova.kristina1069@gmail.com
}

Key words: innovation, borrowing, lexical neologisms, semantic neologisms, author's neologisms, abbreviations, word formation, affixation, telescoping.
The article deals with the basic patterns of formation and functioning of neologisms in modern English-language texts of the beauty industry. The authors raise the problem of distinguishing between the concepts of "neologism" and "innovation" taking into consideration the different points of view of domestic and foreign linguists at the present stage of development of linguistics. The importance of using neological vocabulary in advertising texts as one of the powerful tools for promo among the analyzed innovations, nouns are the most numerous, there are a few adjectives, and verbs are sporadic. Such a disproportion among parts of speech in analyzed words may be explained by the necessity to name new procedures and products that are currently actively appearing in the beauty industry.

The article considers the main structural, grammatical, lexical, and semantic features of neologisms used by advertisers to attract the attention of potential buyers to the product, tool or procedure effectively. According to the method of formation, all examined innovations can be divided into lexical, semantic, authorial (individual-stylistic) ones and abbreviations. The article also analyzes the main morphological ways of word formation of neologisms that function in the beauty texts which are word formation, affixation and telescopy. The body of the study is mainly represented by adjective-noun compounds, which in turn are divided into several subtypes. Nominal compounds are formed according to word-formation models $\mathrm{N}+\mathrm{N}, \mathrm{V}+\mathrm{N}, \mathrm{Adj}+\mathrm{N}$. Adjective compounds are built according to the models $\mathrm{V}+\mathrm{Adj}, \mathrm{Adj}+\mathrm{Adj}$.

Regarding the semantics of the analyzed innovations, they can fall into four lexico-semantic groups: cosmetics, fields of aesthetic medicine and cosmetology, cosmetic and health techniques and procedures, and lexical units to describe cosmetics and decorative cosmetics.

Much attention is paid to the expansion of the beauty industry vocabulary through the processes of borrowing words from other languages and the use of relevant word-formation patterns.
Безперервний розвиток $є$ характерною ознакою сучасного суспільства - щодня в різних сферах людської діяльності, зокрема й у б'юті-індустрії, виникають нові поняття, з'являються нові об'єкти, які потрібують імен, у результаті чого мови світу активно поповнюються неоло- гізмами - новими лексемами або новими значеннями, що їх набувають слова, які вже існують у мовах. Практично жодна галузь не може існувати без неологічної лексики, яку через стрімкість процесу подекуди інколи не встигають фіксувати спеціальні словники. На межі століть надзвичайного 
прориву набула сфера краси, де сьогодні нові терміни створюються миттєво. Проблемою $є$ те, що новоутворена мовна одиниця спочатку нестійка, важко вгадати, чи закріпиться вона в мові і чи стане в кінцевому підсумку словом, яке більшість людей знатимуть i вживатимуть. Важливість дослідження неологічної лексики як частини лінгвальної картини світу будь-якого народу, а також недостатність наукових розвідок, присвячених новій б'юті-лексиці в сучасній англійській мові, зумовлюють актуальність пропонованої статті.

Мета дослідження - визначення специфіки виникнення та функціонування англомовних інновацій у рекламних б'юті-текстах. Досягнення поставленої мети передбачає виконання низки завдань: 1) сформувати корпус дослідження; 2) з'ясувати сучасні шляхи поповнення англійської мови неологізмами сфери краси, визначити моделі їх творення; 3) проаналізувати їхні структурно-граматичні й лексико-семантичні особливості та специфіку вживання в рекламних текстах.

Об'єктом дослідження є неологічні лексеми б'юті-сфери, які були дібрані з рекламних текстів у журналах, блогах, текстах про догляд за собою, адресованих широкому загалу (журнали: Cosmopolitan, PRO, GLAMOUR, VOGUE; блоги: Імідж, \#БЛОГ КРАСА на сайті 1+1, MakeBeauty; сайти косметичних засобів компаній L'Oreal Paris, Maybelline, Nivea тощо). Предметом пропонованого дослідження є структурно-граматичні та лексико-семантичні особливості неологізмів, уживаних рекламодавцями для ефективного привернення уваги потенційних покупців до продукту.

Нові розробки вчених, винайдення та створення предметів для полегшення та пришвидшення темпу життя споживачів спричинюють появу нових слів - неологізмів (від давньогрецьких слів неос - «новий» і логос - «слово»), головною ознакою яких $\epsilon$ абсолютна новизна для більшості носіїв тієї чи іншої мови. Однією з нагальних проблем сучасної неології є відсутність чіткої термінологічної основи - на сучасному етапі розвитку лінгвістики немає єдиного підходу до визначення понять «нове слово», «неологізм» та «інновація», яке останнім часом активно вживається на позначення нової лексики. Так, Є. Карпіловська під терміном «інновація» розуміє нове явище в мові, яке відображається в найактивнішому вияві мовної динаміки [1, с. 3]. В. Гак першим запропонував цей термін «для позначення будь-яких лексико-семантичних нововведень, узуальних або окказіональних» [2, с. 38]. С. Ільясова пише: «Під «інновацією» ми розуміємо нове слово, яке не $\epsilon$ зафіксованим у тлумачних словниках» [3, с. 58].

Дослідження неологізмів має тривалий i системний характер. У своїх працях такі вчені, як
О. Стишов, Р. Фішер, М. Янссен, Л. Нелюбін [4-7] чітко окреслюють поняття «неологізм», виділяють його основні різновиди, 3'ясовують шляхи утворення неологізмів, їхній вплив на носіїв. Однак учені досі не дійшли єдиної думки у трактуванні цього поняття і розумінні його особливостей. Так, О. Стишов стверджує, що неологізми це лексичні одиниці, що виникли в суспільстві для позначення нових явищ і понять, зумовлених науково-технічним розвитком, а також індивідуальних інновацій, які автори поширюють у своїх текстах [4, с. 145]. Р. Фішер підкреслює, що «слова та лексикалізовані словосполучення вважаються новими, якщо вони не були включені до загальних словників стандартної англійської мови» [5, с. 80]. Подібним чином М. Янссен відмічає у своєму дослідженні, що «будь-яке слово, яке не трапляється в морфологічній базі даних, отримане зі словника через його нещодавність, $\epsilon$ неологізмом» [6, с. 7]. Згідно з перекладознавчим словником Л. Нелюбіна, «неологізми - це оказіональні, тимчасові слова, які з'являються в мові тільки в даному контексті, але які іноді набувають права існування в мові в той чи інший час». Той самий словник визначає неологізми як нові слова, які ще не були зареєстровані в перекладених двомовних словниках, або нові значення слів, які вже існують у мові, що не були зафіксовані словниками [7, с. 78].

Неологізм як культурний феномен - один із найважливіших напрямів лінгвістичних досліджень. Процес неологізації притаманний тією чи іншою мірою всім національним мовам, інакше вони не змогли б іти в ногу з розвитком суспільства i забезпечувати комунікативні потреби своїх носіїв у різних сферах людської діяльності [8, с. 201]. Інтенсивний процес оновлення складу лексики у сфері б'юті-індустрії проявляється в iii розширенні різного роду неологізмами, передусім завдяки словотворчим можливостям мови i запозиченню. Нині розвиток досліджуваної сфери орієнтується на досягнення як східної, так і західної цивілізацій (так званий процес «вестернізації»). На думку С. Нетлтон, неологізація мови зумовлюється відкритою орієнтацією різних країн на Захід у сферах економіки, політики, культури, спорту, торгівлі, моди, музики тощо [9, с. 28]. Практично всі вчені стверджують, що неологізми легко відрізнити від інших лексичних одиниць, тому що вони наділені відтінком свіжості і новизни, оскільки позначають ті поняття, які з'явилися недавно і досі всім невідомі.

Неологізми $є$ характерною ознакою рекламних текстів, зокрема i 3 індустрії краси, яка останнім часом активно поповнюється інноваціями; уже наявні терміни набувають нових значень, а також з'являються нові назви б'юті-процедур, 
косметичної продукції та всього, що пов'язано зі світом краси. Працівники сфери, блогери, моделі, рекламні агентства, редактори відомих журналів та всі причетні до б'юті-індустрії, бажаючи іти в ногу із часом, використовують у своєму мовленні ці інновації, часто пояснюють їхнє значення, поки люди не почнуть розуміти і також використовувати їх. Так відбувається процес входження в мову нових слів зі світу краси, який нині переживає так званий «неологічний вибух».

Реклама вже давно стала головною ланкою між виробником і покупцем. Структура сучасного ринку косметики постійно змінюється - 3'являються все більше спеціалізованих магазинів, змінюються способи продажу (особливо в умовах пандемії), покупець стає вимогливішим. Значна кількість доходів б'юті-компаній витрачається на рекламу і піар для просунення асортименту косметичної продукції. Без цього неможливо впливати на ринок і успішно боротися 3 конкурентами за ринки збуту. Тому так важливо «осучаснити» рекламний текст неологізмами, зробити його максимально привабливим для споживачів.

На думку А. Байрачної, неологізми можна розділити за способом утворення на лексичні, семантичні, авторські (індивідуально-стилістичні) i абревіатури [10, с. 99].

Лексичні неологізми, утворені за вже наявними в мові моделями або узятими 3 інших мов, являють собою або окремі слова, або словосполучення. Наведемо приклади: nude (нюд, природний, оголений) - означає популярний тренд на природний макіяж; також може вживатися на позначення природного відтінку шкіри або світло-бежевого (як шкіра) кольору в одязі; tint (відтінок, тон) засіб, який являє собою вид декоративної косметики, що має у своєму складі кольоровий пігмент, який підфарбовує губи, щоки або очі. Приклад такого неологічного словосполучення: lip art (лinapm, «мистеитво на губах») - напрям у мистецтві макіяжу губ, суть якого полягає у відтворенні на губах різних картинок або малюнків.

Семантичними неологізмами $є$ слова, які давно існують у мові, але набули нових значень. Так, від prime (первинний) утворилася лексема primer базовий засіб для макіяжу або манікюру. Нового значення мовна одиниця набула за аналогією до використання грунтовки перед нанесенням фарби на стіну або стелю: спочатку поверхня грунтується, лише потім наноситься фарба. Інший приклад - слово butter у контексті "Watch and feel Almond Body Butter sink into the skin. Butter уживається на позначення інтенсивно зволожуючого крему для дуже сухої шкіри.

Лексичні неологізми відрізняються від семантичних тим, що перші колись існували, але на сучасному етапі виступають вже в іншому осмисленні, а другі $є$ новими значеннями, що додаються до наявних у мові, проте дещо переосмислених слів.

Авторські (індивідуально-стилістичні) неологізми, за А. Байрачною, - слова або значення слова, створені виробником того чи іншого продукту на позначення нових або вигаданих предметів або понять $[10$, с. 99]. Прикладом такого новотвору може слугувати лексема biomatrixing - інноваційна косметологічна процедура для омолодження шкіри шляхом насичення іії необхідними речовинами завдяки нанесенню препарату BioMatrix.

Окрему категорію аналізованих неологізмів утворюють абревіатури, що номінують ті чи інші поняття в б'юті-сфері, наприклад: DD cream (Daily Defence Cream - DD-крем) - це крем для денного захисту шкіри від негативних зовнішніх чинників впливу з легким коригуванням тону, кольору шкіри обличчя. Ще приклади: $\boldsymbol{S W T}$ (Shock Wave Therapy) - косметологічна процедура, суть якої полягає у глибокому проникненні акустичних імпульсів у тканини шкіри, щоб скорегувати тіло; НА (Hyaluronic Acid - гіалуронова кислота) - головний «зволожувач» і один із найпопулярніших компонентів косметичних засобів; через дуже часте використання в косметиці назву скоротили до абревіатури $\boldsymbol{H} \boldsymbol{A}$.

Окрім згаданих вище груп інновацій, можна також виділити морфологічні неологізми, що створюються за зразками, які існують у мовній системі, та 3 морфем, що є в даній системі [11, с. 95]. Морфологічні неологізми зазвичай репрезентують шар пасивної лексики, із часом реєструються словниками, формуються продуктивними способами словотворення і не мають авторства. Новим і унікальним можна вважати слово biorevitalization (біоревіталізачія) - це процедура введення мікроуколів гіалуронової кислоти під шкіру для стимулювання регенерації та досягнення омолоджуючого ефекту, тобто біологічна активізація (англ. biological revitalization).

Основними морфологічними способами словотворення досліджуваних неологізмів $є$ словоскладання, афіксація та телескопія.

Відзначимо досить численну групу інновацій у досліджуваній сфері, утворених шляхом поєднання двох слів разом. Так, у слові longwear у контексті "No other longwear lasts longer period" прикметник long приєднався до іменника wear, у результаті чого виник новий іменник longwear, який використовується для характеристики стійкості помади. Наведений приклад $\epsilon$ прикметниково-іменною (номінальною) сполукою. Іменні сполуки можна поділити на три підтипи:

1) $\mathrm{N}+\mathrm{N}$ (flowerbomb - парфумована вода від Viktor \& Rolf нагадує квітковий вибух, після якого жінка відчуває пахощі різноманітних квіткових 
відтінків; lipperfection - підназва блиску для губ, який робить їх ідеальними);

2) $\mathrm{V}+\mathrm{N}$ (fade-defiance - техніка, за якою створюється нечіткий «димчастий» перехід від короткого волосся на потилиці до будь-якої бажаної довжини на маківці; grow-lash - засіб для росту вій);

3) Adj + N (deepshine - лінійка засобів для волосся, які надають йому глибокого сяйва; longwear - властивість помади, колір якої може залишатися на губах протягом багатьох годин).

Прикметникові сполуки можна розділити на два підтипи:

1) $\mathrm{N}+$ Adj (colorsensational - помада Color Sensational кремової текстури 3 різноманітною палітрою відтінків, яка надає губам насиченого кольору, photoready - професійна основа під макіяж, до складу якої входять фотохроматичні пігменти, що розсіюють світлові промені, у результаті чого шкіра виглядає бездоганною в будь-якому освітленні);

2) Adj + Adj (magicsmooth - засіб для шкіри, який робить шкіру надзвичайно гладкою; sexysassy - косметика 3 афродизіаками).

Афіксація $\epsilon$ ще одним продуктивним способом утворення неологічних лексем у сфері краси. Наприклад, у слові ultra-fine у контексті "Ultrafine powder for polished, seamless coverage”, префікс ultra- («вищий ступінь») було додано до прикметника fine, у результаті чого шляхом префіксації виник новий прикметник ultra-fine (про пудру - дрібнодісперсна). Також інновації аналізованої сфери можуть утворюватися за допомогою суфіксів: blushable (такий, що може викликати рум'янець) і millionize (помножити на мільйон).

Сучасна англійська мова характеризується активним використанням телескопії для створення неологічної лексики. За словами А. Лерера, «телескопія - спосіб утворення нових лексичних одиниць, який полягає в накладанні однієї морфеми одного вихідного компонента на морфему іншого вихідного компонента» [12, с. 359]. Сфера краси не стала винятком. Усічені частини двох окремих слів об'єднуються разом для створення єдиної лексеми. Наприклад, у слові liplicious у контексті "Liplicious Moisturizing Balm SPF 15", початок слова lipstick поєднано 3 кінцем слова delicious. Нова лексема liplicious позначає бальзам для губ м'яких кольорів і $з$ тонкими фруктовими ароматами. Існує чотири основні види телескопії. Перший тип - це комбінація початкової частини першого слова та заключної частини другого, наприклад: liplicious (lipstick та delicious), cosmedicine (cosmetic i medicine). Другий тип - це поєднання цілого слова та завершальної частини другого слова, як у лексемах purescreen (pure i sunscreen) i sparitual (spa i spiritual). Третій тип - це поєднання початкової частини першого слова i цілого слова, як у lipclick (lipstick та click) і botafirm (botanic та firm). Останній тип - це комбінація початкової частини першого слова та початкової частини другого слова: mani-pedi (manicure i pedicure).

Щодо частиномовної приналежності, то аналіз дібраних неологізмів показав, що здебільшого інновації є іменниками, що з'являються на ринку краси у зв'язку з необхідністю давати назви новим продуктам, процедурам чи послугам. Рідше у процесі неологізації утворюються прикметники, ще рідше - дієслова. За допомогою прикметників можна незвичайно описати продукт, щоб споживач його забажав; за допомогою дієслів можна показати унікальну дію продукту, процедури або послуги.

Подекуди для створення нового слова може бути задіяно декілька способів словотворення одночасно. Наприклад, слово natureluxe у контексті "New natureluxe silk foundation" виникло в результаті об'єднання процесів запозичення (фр. luxe) і складання (nature + luxe). Лексема показує, що цей тональний крем зроблений із натуральних інгредієнтів, він може зробити ваше обличчя природно блискучішим, більш гладким та шовковистим.

Відомо, що індустрія краси нині є одним із найбільш динамічних і перспективних напрямів людської діяльності. Постійно розширюються потреби людей, які бажають бути здоровими, активними, успішними і красивими, з'являються нові косметологічні напрями, процедури, створюються нові косметичні продукти. Названі процеси відображаються в мові, яскраво проявляються в лексико-семантичному полі «Краса та догляд», яке, на нашу думку, зараз входить у число домінантних лексико-семантичних полів сучасної мови.

Аналіз фактичного матеріалу дозволив виділити чотири лексико-семантичні групи дібраних інновацій. Розглянемо їх детальніше:

1) найменування косметичних засобів та їхніх інгредієнтів (наприклад: butter, DD cream, primer, HA, tint);

2) найменування напрямів естетичної медицини і косметології (antiaging - новий розділ медицини, який опікується тим, щоб повернути людям молодість);

3) найменування косметичних i оздоровчих методик і процедур (biomatrixing, SWT, biorevitalization);

4) лексеми для опису декоративної косметики та косметичних засобів (наприклад: lipperfection, liplicious, colorsensational, ultra-fine, natureluxe, longwear, nude, grow-lash, deepshine, photoready, magicsmooth, sexysassy). 
У результаті проведеного дослідження доходимо таких висновків. Інновації відіграють дуже важливу роль у текстах б'юті-сфери, зокрема й рекламних. Такі лексеми репрезеновані абревіатурами, лексичними, семантичними, авторськими, а також морфологічними неологізмами, які утворюються за допомогою словоскладання, афіксації та телескопії. Найчисленнішими у сфері $€$ іменникові інноваціі. Також можемо говорити про можливість виділення кількох лексико-семантичничних груп проаналізованих лексичних одиниць. Правильне використання різних способів утворення інновацій допомагає зробити текст реклами індвивідуальним, таким, що легко запам'ятовується, що в результаті приводить до збільшення попиту на товар. У тексті сучасної реклами неологізми стали одним 3 основних елементів слоганів товарів. Уважаємо подальші дослідження в цьому напрямі перспективними, оскільки вони можуть стати у пригоді спеціалістам б’юті-індустрії, сфери реклами тощо.

\section{ЛІТЕРАТУРА}

1. Карпіловська Є. Зміни у структурі сучасної української мови та можливості їх моделювання. Украӥнська мова. 2011. № 2. С. 3-18.

2. Гак В. О современной французской неологии. Новые слова и словари новых слов. Ленинград, 1978. C. 36-57.

3. Ильясова С. Новые реалии общественно-политической жизни и их отображение в инновациях (на материале инноваций конца ХХ в.). Филология и культура : тезисы II Международной конференции / отв. ред. Н. Болдырев. Тамбов : ТГУ, 1999. 134 с.

4. Стишов О. Українська лексика кінця XX ст. (на матеріалі мови засобів масової інформації) : монографія. Київ : Вид. центр КНЛУ, 2003. 392 с.

5. Fischer R. Lexical Change in Present-Day English : A Corpus Based Study of the Motivation, Institutionalization, and Productivity of Creative Neologisms. 1998. 209 p.

6. Janssen M. Orthographic Neologisms Selection Criteria and SemiAutomatic Detection. Portugal : ILTEC, 2002. 24 p.

7. Нелюбин Л. Толковый переводоведческий словарь. Москва : Флинта: наука, 2003. 320 с.

8. Gerhardt C., Frobenius M., Ley S. Culinary Linguistics. The Chef's Special. John Benjamins Publishing Company, 2013. 345 p.

9. Nettleton S. Sociology of Health and Illness. Third Edition. Cambridge : Polity Press, 2013. 344 p.

10. Байрачна А. Неологізми як один із головних факторів розвитку української мови. Управління розвитком. 2014. № 12. С. 99-100.

11. Александрова О. Неологизмы и филология. Вопросы современного словообразования лек- сики и стилистики : научная работа. Самара, 2016. C. 325.

12. Lehrer A. Identifying and Interpreting Blends : An Experimental Approach. Cognitive Linguistics. Berlin; New York, 1996. Vol. 7. № 4. P. 359-390.

\section{REFERENCES}

1. Karpilovska, Ye.A. (2011). Changes in Ukrainian language structure and possibilities of their modelling [Zminy v strukturi suchasnoiukrainskoi movy ta mozhlyvosti ih modeluvannia]. Ukrainska mova. № 2. Pp. 3-18.

2. Gak, V.G. (1978). About modern French neology [O sovremennoi frantsuzskoi neologii]. New words and dictionaries of new words. Leningrad, pp. 36-57.

3. Ilyasova, S.V. (1999). New realities of social and political life and their reflection in innovations [Novye realii obshchestvenno-politicheskoy zhizni i ikh otobrazhenie $\mathrm{v}$ innovatsiyakh (na materiale innovatsiy kontsa XX v.). Filologiya i kultura : Tezisy II mezhdunarodnoy konferentsii / Ed. Boldyrev, N.N. Tambov. 134 p.

4. Styshov, O.A. (2003). Ukrainian vocabulary of the late 20-th century [Ukrainska leksika kintsya XX stolittya (na materiali movi zasobiv masovoi informatsii)] : Monografiya. Kyiv : Kyiv National Linguistic University Publishing Center, 392 p.

5. Fischer, R. (1998). Lexical Change in PresentDay English: A Corpus Based Study of the Motivation, Institutionalization, and Productivity of Creative Neologisms, $209 \mathrm{p}$.

6. Janssen, M. (2002). Orthographic Neologisms Selection Criteria and SemiAutomatic Detection. Portugal : ILTEC, $24 \mathrm{p}$.

7. Nelyubin, L.L. (2003). Definition dictionary of translation [Tolkovyy perevodovedcheskiy slovar]. Moscow, 320 p.

8. Gerhardt, C., Frobenius, M., Ley, S. (2013). Culinary Linguistics. The Chef's Special. John Benjamins Publishing Company. 345 p.

9. Nettleton, S. (2013). Sociology of Health and Illness (3-rd edition). Cambridge : Polity Press, pp. 28-32.

10. Bayrachna, A.V. (2014). Neologisms as one of the main factors for Ukrainian language development [Neologizmi yak odin iz golovnikh faktoriv rozvitku ukrainskoï movi]. Upravlinnya rozvitkom. № 12, pp. 99-100.

11. Alexandrova, O.I. (2016). Neologisms and Phylology. Issues of modern word-formation and stylistics [Neologizmy i filologiya. Voprosy sovremennogo slovoobrazovaniya leksiki $i$ stilistiki: Nauchnaya rabota]. Samara : Samara State Pedagogical Institut, p. 325.

12. Lehrer, A. (1996). Identifying and Interpreting Blends: An Experimental Approach. Cognitive Linguistics. Berlin ; New York. Vol. 7. № 4, pp. 359-390. 